\title{
Public Policies for Food Security and Rural Development in a Brazilian Cooperative
}

\author{
José Aparecido Pereira $^{1}$, Vanilde Ferreira de Souza-Esquerdo ${ }^{2} \&$ Carolina Rios Thonsom $^{3}$ \\ ${ }^{1}$ Family Farming Cooperative named Cooperacra, Americana, SP, Brazil \\ ${ }^{2}$ College of Agricultural Engineering, University of Campinas, Campinas, SP, Brazil \\ ${ }^{3}$ Institute of Philosophy and Human Sciences, University of Campinas, Campinas, SP, Brazil \\ Correspondence: Vanilde Ferreira de Souza-Esquerdo, College of Agricultural Engineering, University of \\ Campinas, Av. Cândido Rondon, 501, Barão Geraldo, 13083-875, Campinas, SP, Brazil. Tel: 55-19-3521-1063. \\ E-mail: vanilde.esquerdo@feagri.unicamp.br
}

$\begin{array}{lcc}\text { Received: June 11, } 2018 & \text { Accepted: July 24, } 2018 & \text { Online Published: September 15, } 2018 \\ \text { doi:10.5539/jas.v10n10p415 } & \text { URL: https://doi.org/10.5539/jas.v10n10p415 }\end{array}$

\begin{abstract}
PAA (Food Purchase Program) and PNAE (National School Feeding Program) are known worldwide as pioneers public policies on fighting food insecurity and rural poverty. We have analyzed the participation of a family farmers' Cooperative on such programs as a supplier of organic products. Both programs revealed to be economically relevant and promote local governance if well executed, depending on the level of commitment from local administrations, beneficiaries and farmers. However, both are yet highly sensible to governmental changes as we've identified municipalities that explore their fully potential and others which do not engage, even though Brazilian law requires them so.
\end{abstract}

Keywords: family farming, public policies, rural development

\section{Introduction}

Family Farmer is a relatively recent category that gained governmental recognition in the 1990's in Brazil. It's a plural reference, related both to the traditional European notion of peasantry and also to indigenous, black rural and fishermen communities, among others. The Brazilian notion of family farming resides in the social and economic link between the rural family and the activities developed in the land in which they live at. It must be a place of both work and living. It's a notion opposed to entrepreneur agriculture, characterized by large areas of monoculture and paid employment.

Brazilian rural history is marked by family farmers' exclusion from public policies. The roots for so remains in the country's colonization, which traced a development model that pursues a large-scale production of commodities for exportation. Such model has been followed by national governments over the past five centuries as one of the most important strategies for the country's economic growth.

Still nowadays agribusiness related activities represent the major part of Brazilian exportations and contribution to the Internal Gross Product. However, as a direct consequence, it has marginalized smaller farmers without the demanded capital and access to land to be included on such type of productive chain. Especially since the 1960's, this process has become even profounder as the access to machinery and productive technologies started to be highly promoted and subsided by Brazilian government in benefit of large producers.

In addition, as there was never an effective land reform in the country, there is a historical yet actual tendency towards increasing land concentration. Through the past five decades, most family farmers have abandoned their original activities and migrated to urban areas as the mentioned development model advanced in our countryside. On the other hand, the ones which stayed are mostly living under constant economic insecurity and are the families that set rural poverty in Brazil as an urgent and modern problem. A study carried on by Soares et al. (2016) revealed that rural poverty in Brazil is directly linked to the lack of access to land, as $81 \%$ of those living in rural households occupy an area considered insufficient for a family's survival.

The numbers from the most recent agricultural census from 2006 also reveals the level of land and income concentration in Brazil as a result of such process. Family farming is responsible for $84.4 \%$ of rural properties, yet 
it occupies $24.3 \%$ of lands suitable for human exploitation (IBGE, 2006). Furthermore, family farming is also responsible for employing $74.4 \%$ of people in rural activities, which means $25.5 \%$ of the economically active population in the country (IBGE, 2006). However, when it comes to their revenues, family farmers generate only $1 / 3$ of the income from agricultural activities in the country, an average of 13 thousand reals per year/per property.

According to Wanderley (2001), one of the strategies that allows family farming to resist in rural areas is its type of production. Family farmers which do not have access to modern technologies or choose not to specialize in conventional production, commonly produce different kinds of products which are characteristically for human feeding. Besides their main activity, such as cropping and/or dairying, they commonly have animals for the families consume of protein as well as vegetable and fruit gardens around the household. Such habits have also contributed to the fact that in Brazil family farming typically produces for domestic supply and has been highly exploited by middlemen, the government and food industry throughout history, in order to keep the cost of feeding on low levels.

Still nowadays, one of the biggest obstacles faced by family farmers to keep its economic sustainability is marketing their production. The marketing channels for family farming up to the beginning of this century can be considered complicated due to the unfair and biased competition with large wholesalers.

The Food Purchase Program (PAA) and the PNAE (National School Feeding Program) represented two pioneers experience by the federal government to deal with this situation. The PAA has been created in 2003 and it results from two major debates that gained relevance in the late 1990s. The first one is related to the discussion on food and nutritional security and the importance of public power into assisting the population at food insecurity risk. The other concerns the importance of public power on supporting family farmers trough the payment of better prices for their productions as a key strategy for overcoming rural poverty (Grisa et al., 2009).

Therefore, PAA has been developed setting the government as the responsible for acquiring products from family farmers on fair and constant prices and mediating its distribution for public institutions in which the population at food insecurity risk is attended.

Even though the federal government is a key actor, the governance of PAA is supposed to be multi-sectorial and involve civil society as well as different levels of the public administration. At a National level the Program is monitored by the National Council for Food and Security (CONSEA), other governmental organizations, and representatives from Civil Society. The most important institutions in its operationalization are CONAB (The National Supply Company), SEAD (Secretariat of Family Farming and Rural Development) and the Ministry of Education (MEC). Its management groups also include representatives of the Ministry of Social Development (MDS), the Ministry of Finance (MF), the Ministry of Planning and Management (MPOG) and the Ministry of Agriculture, Livestock and Supply (MAPA). In addition to these, the program has local managers who can be representatives of cooperatives or associations of family farmers, which support the municipal or the state government on planning, controlling, supervising and implementing the logistics of PAA.

The acquisition of products from public administration through PAA can happen through six modalities, among which there is one named simultaneous donation. The purchase thorough simultaneous donation means that the products acquired by the governments are donated to philanthropic and welfare entities and also to communitarian restaurants, communitarian kitchens and food banks. This is the modality which we will be analyzing on this study.

The other program which will be focus of this study is the PNAE. Such one has been created in the 1950s, however only in 2009 it has developed a specific link with family farming. Since then, by law, at least $30 \%$ of the total resources passed on by the National Education Development Fund (FNDE) to the states and municipalities in order to acquire products for school meals ought to be purchased from family farming (MDA, 2010). It's also important to mention that if the delivered products are organic, both Programs pay 30\% more than the value paid for conventional products in the regional markets.

This paper analyses the participation of a Family Farming Cooperative named Cooperacra in both programs. Cooperacra's headquarters is located in the municipality of Americana, State of São Paulo, Brazil, and currently it has 34 members. The Cooperative's production is organic and at the time they delivered its products to two municipalities in the state of São Paulo through contracts of PAA and PNAE. We have gathered information about these experiences through observational research, interviews and additional data reports provided by the Cooperative's managers.

\section{Methodology}

For the development of this research data was collected through qualitative methodologies such as participatory observation and non-directive interviews, conducted during the second semester of 2014 and first semester 2015. 
Participatory Observation was used to identify the difficulties faced by Cooperacra's farmers to market their products to PAA and PNAE. As for the non-directive interviews, the matters addressed by the researchers were elaborated after a period of observation. Instead of questions, the researchers presented topics to the interlocutors, who reflected and reported on them. The interviews were carried out with four members of the cooperative.

Data and information have been collected in the field as well in meetings held by the cooperative. Thus, there was a follow-up of the various activities carried out by the cooperative, ranging from participation in planting and administrative activities to monitoring the marketing of products delivered to PAA.

We have also had access to data provided by the Cooperative's border related to its contracts for PAA and PNAE, containing amounts and prices paid for the delivered products. Such type of data is rarely analyzed, as normally, only general data published by the government regarding the global amount of contracts is accessed. Furthermore, bibliographical research over other studies of PAA an PNAE in the region was conducted in other to subside the comparative analyses shown in our results and conclusion.

\section{Results and Discussion}

\subsection{A Brief Historical Over Cooperacra and Its Operationalization}

According to our interviews and the Cooperative's analyzed documents, we've identified that in 2008 a group of Family Farmers from the city of Americana founded Cooperacra with the support of members of the Catholic Church, NGOs, universities and research institutes. At the time, the members felt the need to form such organization in order to expand the marketing area of their products and obtain the recognition of their organic production.

At Cooperacra the families can be involved at the cooperative's activities in three manners. On the first case, there are two collective areas managed by the cooperative in which members can participate on the production together and the planning is done collectively as well. A second one in which each family plans the production and work on its property according to the cooperative's delivery planning and it's also common that in such degree of involvement the cooperative's members exchange working days between properties. And the third way, in which other families use the cooperative's space to solve only isolated marketing problems and in this case there is no exchange of working days or much collective participation on the production planning.

Even though there are such different levels of engagement, all members take part in the PAA and PNAE and are members of the Cooperative's Participatory Guarantee System (PGS). A PGS is a collective form of attesting organic quality in Brazil. The farmers form local groups of audition and inspection and they are responsible for guaranteeing the organic quality of their products.

The observational research revealed that the Cooperative's members have a very large diversity of production. They produce, for example, green corn, spinach, chili, parsley, chives, rocket, zucchini, pumpkin, tomato, carrot, radish, cassava, beet, onion, eggplant, chuchu, cabbage, cauliflower, kale, yam, broccoli, banana, jackfruit, avocado, mango, strawberry, passion fruit, among others. These products are partially exchanged and consumed by the Cooperative's families and the surplus is commercialized. At the time of the research, their main markets channels were PAA and PNAE.

\subsection{The Experience of PAA in Cooperacra}

The PAA started to be operationalized in Americana at the beginning of 2014, as eight entities that attended population under food insecurity from the municipality were registered as potential receivers of food donation. One year after, the total number of entities authorized by the program as receivers reached 22 .

The members of Cooperacra related that even before the creation of PAA, Cooperacra had the practice of donating part of its production to social assistance entities that had financial difficulties during the 1990's. After the beginning of the PAA in 2014, the main change related to the fact that Cooperacra began to deliver food in a more organized way and to receive governmental payment for it. As soon as the PAA was established, the Cooperative formalized one of these types of philanthropic donations that it had already been practicing previously,

Cooperacra takes part into PAA through a contract modality named simultaneous donation. In such modality, it is compulsory that family farmers are part of cooperatives or associations. The government acquires fresh, processed or industrialized products from such organizations in order to donate these products to local entities that attend local population under food insecurity. The main goal into this modality is to enrich the variety of menus provided by the receiver entities to its attended public.

As for its operationalization, every year a list of demanded products is published by the government through CONAB (The National Supply Company) for the participant farmers' organizations. Such list contains which 
products are demanded by the receivers entities and which are the respective values that will be paid for each. Food purchase prices are defined by the average of three price surveys done at local or regional wholesalers in the last 12 months. As Cooperacra has its organic certification trough a Participatory Guarantee System, it receives a bonus of $30 \%$ over the conventional prices related above.

The farmers' organization must submit a proposal in order to participate in the Program, informing which producers will take part in the proposal, which products from the list presented by CONAB will be delivered, in what quantities and pointing out the entities that will be served and the period of validity of the proposal. In this way, PAA allows farmers to participate delivering according to their type of products and capacity of production.

After the delivery of the products, CONAB transfers the agreed amounts to the account of the organization, which, in turn, makes the payments to the farmers. The payment is made to the supplier organization after the final conclusion of the accounts, which requires the following documents: final sales note to CONAB, deadline for receipt and acceptance, delivery report and payments report (required from the 2 nd delivery). This modality has an acquisition limit of 8 thousand Brazilian reals per family per year and up to 2 million Brazilian reals per organization per year.

As for the delivery logistic, in the case of Cooperacra the receivers entities dislocate to the Cooperative's shed to withdraw the products. During the interviews, the farmers declared that this is a highlight related to the Program, since there are no expenses with packaging as the products are placed in plastic boxes that are then transferred by the beneficiaries. Furthermore, transportation costs are not under the cooperative's responsibility.

The data provided by Cooperative's border revealed that in 2014, Cooperacra attended the PAA delivering 17,115 $\mathrm{kg}$ of organic food and 20 different types of products. In 2015, it had already attended the PAA with the delivery of 22 different items, however, the contract was still ongoing during the time of this research conclusion.

\subsection{The Experience of PNAE in Cooperacra}

As it occurred in the case of PAA, our interviews and the Cooperacra documents' also revealed that even before taking part in the PNAE, from 1992 to 1995, Cooperacra had a previous experience on delivering food to local schools through contracts with the municipal administration of Americana. However, as the municipal administration changed after following elections, the agreement was interrupted.

As seen before, after 2009 the law regarding PNAE changed and it made compulsory that at least $30 \%$ of schools meals acquired for public schools by the municipal and state administrations originated from family farming. However, not all administrations fulfilled this new goal, and even in 2018 there are still cases in which the resources reserved to this $30 \%$ is returned to the federal government. In the analyzed region, the first municipality that adapted to the requirement was not Americana, but Santa Bárbara do Oeste, a neighbor city. Cooperacra started to take part of the Program since the first year of its operationalization in 2011.

Regarding the PNAE's contracts, Cooperacra is responsible for providing meals to 89 schools in Santa Barbara do Oeste. In 2015, besides Santa Barbara do Oeste, Cooperacra also started to deliver food to schools at another neighbor municipality named Rio das Pedras. We have had access to the amount of products delivered by Cooperacara to both municipalities in 2015 through PNAE. The amounts and types of products can be seen on Table 1. 
Table 1. PNAE: Items delivered by Cooperacra to schools in Rio das Pedras and Santa Bárbara do Oeste in 2015

\begin{tabular}{|c|c|c|}
\hline Products & Rio das Pedras Quantity $(\mathrm{Kg})$ & Santa Bárbara do Oeste Quantity $(\mathrm{Kg})$ \\
\hline Banana & 4.000 & 11.000 \\
\hline Lemon & 500 & - \\
\hline Passion Fruit & 5.000 & 1.500 \\
\hline Strawberry & 100 & 3.000 \\
\hline Acerola & 100 & - \\
\hline Pumpkin & 300 & - \\
\hline Sweet Potato & 300 & - \\
\hline Zuchinni & 300 & 2.000 \\
\hline Carrot & 500 & 5.000 \\
\hline Chuchu & 200 & 1.500 \\
\hline Manioc & 500 & 2.500 \\
\hline Cucumber & 400 & - \\
\hline Pod & 200 & - \\
\hline Lettuce & 2.000 & 5.000 \\
\hline Brocolis & 200 & 2.000 \\
\hline Parsley & 300 & 2.500 \\
\hline Cabbage & 100 & 2.000 \\
\hline Cabbage & 300 & 3.000 \\
\hline Rúcula & 100 & 2.000 \\
\hline Beetroot & - & 3.000 \\
\hline Espinach & - & 2.000 \\
\hline Okra & - & 2.000 \\
\hline Radicchio & - & 3.000 \\
\hline Avocato & - & 1.500 \\
\hline Eggplant & - & 1.500 \\
\hline Onion & - & 1.500 \\
\hline
\end{tabular}

Source: Research data, 2015.

As for the logistics of PNAE, differently from PAA, the deliveries of the products are carried out by the Cooperative. The listed products are picked on mondays, then taken to the cooperative's warehouse where, after being separated, they are inspected in size and quality, cleaned, weighted and packaged. On Tuesdays, the food is delivered at the kitchens of the beneficiary municipal schools. This work was performed by two members of the cooperative, taking at least 10 hours to be executed.

While comparing PAA and PNAE, for Cooperacra PNAE revealed to be the best income generator from all its revenues sources. Santa Rosa, Lucas, and Garavelho (2011) have already demonstrated that Cooperacra's gross annual income increased by $575 \%$ after taking part into PNAE.

\subsection{Discussion on the PAA and PNAE's Experiences}

During the research, we had the opportunity to take part in the products' separation at the Cooperacra's warehouse for both PAA and PNAE deliveries. We have observed that he quality service is carried out with attention, avoiding to the maximum sending rotten or esthetically bad looking products. When asked about their quality standard while separating products, the cooperative's members responsible for the task declared that their motto is "Cooperacra does not sell what it does not consume".

We have also taken part in deliveries for PNAE and observed while the receivers from PAA withdrew the products ate the Cooperative's headquarters. On these interactions, we have notest that even though there is such attention during the products selection, there are still complaints from receivers regarding the products' uniformity, which commonly present different sizes and shapes. The cooperative's members pointed out such absence of uniformity as a challenge, even if the products are fresh and perfect for consume.

During the deliveries at schools for PNAE we have also registered declarations from kitchen chefs regarding the resistance of students on consuming some of the provided products. They have pointed out difficulties on developing menus including, for example, beetroots, spinach, carrots, bananas, radicchios and eggplants. The 
arguments presented by the chefs are of two kinds, some declared that students do not like and do not consume them, and some admitted a lack of knowledge on preparing unconventional menus with such products.

When receivers from both PAA and PNAE were inquired about the importance of the Programs for their institutions, they highlighted its importance in terms of food security and expressed joy for having a direct contact with providers. However, most of them did not know mention the fact of the accessed food being organic, or even acknowledge the importance of consuming them in terms of nutritional quality and health security. On the other hand, it is interesting to note that when the Cooperative's members responsible for the withdrawal of food where inquired about the importance of the Programs, they showed an opposite approach. The farmers highlighted the fact of their products being organic and mentioned proudly that they were able to provide a great variety of products rarely accessed by the attended public, such as green corn, strawberries, tomatoes, carrots, jabuticabas and peppers.

Such results reveal how the urbanization process has led children, young people and even many adults to be unaware about the origins of food. Before PAA and PNAE, municipal administrations mostly bought processed products from major wholesalers in order to provide meals for local institutions. Typically, such meals were readymade and artificially flavored, including artificial juices, highly processed meat (sausages and ham), industrialized biscuits, among others. Almost none in-natura products were acquired and even when they were, there was no diversity and they were not organic.

As for the operationalization of contracts from PAA and PNAE, the interviews and field research revealed that the biggest difficult faced by Cooperacra relates to the commitment made by the rural producer to deliver a specific type of product in an amount previously determined. The farmers declared that the main reason for so is because climate has been changing drastically in the region and there isn't always-sufficient water for irrigation, neither guaranteed access to adequate and available organic inputs, such as seeds and fertilizers. Such conditions generates a constant feeling of insecurity related to the expectation if producers will actually comply with the weekly deliveries they are ought to carry out.

However, Cooperacra has come up with an important strategy to deal with this situation. The farmers related that they have started to plant collective in two areas besides their own properties in order to guarantee surplus and maintain the delivers according to the previewed. As well, they have started to produce in areas of other partner cooperatives in neighbors municipality, such as Limeira, Piracicaba, Cordeirópolis. The surplus of these areas are also used to cover the voids of individual farmers. This is an important strategy identified during the research, as only collectively they were able to tackle production instability. This would have been impossible if they were not delivering through a cooperative system.

Another problem that producers declared to face is the bureaucracy for PAA and PNAE eligibility, because not all farmers have the Declaration of Aptitude for Pronaf (DAP). The DAP is the main document that that recognizes a producer as a family farmer and therefore allows him or her to take part in PAA and PNAE. However, the government commonly emits only one DAP per property and when the work is performed by a couple or more than one family member, such limitation significantly reflects in the family income. At Cooperacra, for example, 30 producers are directly involved into producing for both Programs, but only 24 possess DAPs. At Cooperacra the members have decided that the 30 individuals should divide the payments proportionally. However, as one can see, this is a great limitation for the Cooperative's revenues in total.

In this sense, an important advance happened in march 2015, as the PNAE was partially modified in terms of limits for payments. Before, the limit of 20 thousand reals per year was linked to each individual farmer and even if one of them did not deliver up to this amount, the financial resource available for his or her payment would have been lost. Now, there is a general limit available per organization according to the number of farmers times 20 thousand Brazilian reals. For family farmers, this is a very significant advance, since it allows the rural producer to formalize contracts for deliveries of products to school meals according to what their production supports and the Cooperative members to distribute proportionally their resources without loses.

Another problem relates to the difficult of taking part into PNAE and PAA on other municipalities and expand the Cooperative's markets. As mentioned before, at Americana, the city where Cooperacra is based, there was still no contract for PNAE in 2015. We've started to investigate the reasons for so and our field research and interviews revealed that actually there had been a public call carried out by the municipal administration in 2014. At the time, Cooperacra and other regional farmers' organizations had been selected to deliver to local schools through PNAE. However, the municipal administration itself recommended not formalizing the contract, as they declared not to have the financial resources to process the payment for being severely indebted. We have found out that the 
municipal administration, which had been elected in two consecutive terms by the time of our research, was under investigations and the mayor's mandate to be annulled.

In the municipality of Nova Odessa, another neighbor municipality, public calls for the supply of food for school meals did not go off paper. The board of Cooperacra had several meetings with the public agencies of this municipality, but the municipality still does not acquire at least $30 \%$ of its school meals from family farmers as supposed according to the law. As well, the Municipal Government of Jarinu has in 2010 and 2011 organized meetings to promote and consolidate PNAE in the municipality. At the time, two public calls were published. However, the administration was unable to obtain sufficient subscriptions from local producers because the amount paid annually at the beginning of the program was only 9 thousand reals per year per DAP and most local farmers considered this amount too low. In cases like this, previous studies have demonstrated that it's even more interesting to sell through conventional market channels such as wholesalers (Souza-Esquerdo \& Bergamasco, 2013).

We have observed that there was a constant attempt from Cooperacra's directive board to find new market channels, as there was still great surplus from the farmers' production. Its members are constantly involved in meetings with local administrations and other organizations of civil society in order to discuss the conditions of family farmers in the region and their conditions for producing and marketing their products. Its president, for example, was currently also the president of the Municipal Council for Food and Security (CONSEA) from American, in which schools' representatives, philanthropic institutions and local government discuss strategies for rural development and food security. The president declared that he considers this political space very important, because it facilitates the meeting of several representatives from various sectors of the population, contributing, thus, to the exchange of experiences, discussions of local problems and possible attitudes. Still, he revealed that the governance potential of CONSEA is highly dependent on the elected municipal administration, because it determines how easily its work can flow.

\section{Conclusions}

In the studied region, PAA and PNAE allowed Cooperacra to become the main deliver of organic food to schools and institutions that attend a public under food insecurity risk. Both programs came to guarantee access to balanced and healthy food for a vulnerable parcel of the local population and at the same time to promote social and economic sustainability of family farming. This study has showed that it is a possible task when public power, farmers and beneficiaries dialogue and commit to the programs.

An important limitation observed relates to the difficulty faced by producers on planning their production to meet the demands of the Programs. If producers are not aware of when public calls will be launched and which products will be related to school meals, then they are also not sure what, when and how much to plant. Therefore, there should be an ongoing schedule of local administrations to maintain a buyer/seller relationship.

In order to advance in terms of local governance, we believe that there should be more exchange between farmers and beneficiaries. This could reinforce the programs' objectives besides guaranteeing a popular consolidation of both in several municipalities - specially those in which the public administration is not committed to executing the programs. Cooperacra's members have, for example, declared that it would be very gratifying to know what students, teachers and school leaders think about the organic products they deliver.

Furthermore, we would like to highlight the limits of delivering per DAP, the high cost of deliveries in PNAE and the inadequacy of the menu presented in the public calls with the production of family farming as the main remaining problems for the Programs' successful operationalization. Both revealed to be economically relevant and promote local governance if well executed, depending on the level of commitment from local administrations, beneficiaries and farmers. However, both are yet highly sensible to governmental changes as we've identified municipalities that explore their fully potential and others which do not engage, even though Brazilian law requires them so.

\section{References}

Abramovay, R. (1999). Uma nova extensão para a agricultura familiar (p. 222). Anais do Seminário Nacional de Assistência Técnica e Extensão Rural.

Bergamasco, S. M. P. P., \& Norder, L. A. C. (2003). A alternativa dos assentamentos rurais: organização social, trabalho e política. São Paulo: Terceira Margem.

Castro, T. P. (2014). A contribuição do Programa Nacional de Alimentação Escolar (PNAE) para a reprodução camponesa: Um estudo de caso da Associação Comunitária Rural Alvorada (ACRA) (Dissertação, Mestrado 
em Geografia Humana, Faculdade de Filosofia, Letras e Ciências Humanas, Universidade de São Paulo, São Paulo).

FNDE. (2015). Aquisição de produtos da agricultura familiar para o Programa Nacional de Alimentação Escolar. Retrieved May 15, 2015, from http://www.fnde.gov.br/programas/alimentacao-escolar/agricultura-familiar

Grisa, C., Schmitt, C. J., Mattei, L. F., Maluf, R. S., \& Leite, S. P. (2009). O programa de Aquisição de Alimentos (PAA) em perspectiva: Apontamentos e questões para o debate. Seminário Temático Programa de Aquisição de Alimentos (PAA). Juazeiro, BA. Retrieved from http://oppa.net.br/acervo/publicacoes/Pesquisa_AABROPPA_Texto_PAA_versao_livro.pdf

IBGE. (2006). Censo agropecuário 2006. Rio de Janeiro: IBGE. Retrieved from http://www.ibge.gov.br

MDA. (2010). Lei $n^{\circ} 11.947$, de 16/06/2009: Dispõe sobre o atendimento da alimentação escolar e do Programa Dinheiro Direto na Escola aos alunos da educação básica; altera as Leis nos 10.880, de 9 de junho de 2004, 11.273, de 6 de fevereiro de 2006, 11.507, de 20 de julho de 2007; revoga dispositivos da Medida Provisória no 2.178-36, de 24 de agosto de 2001, e a Lei no 8.913, de 12 de julho de 1994; e dá outras providências. Brasília, DF. Retrieved May 15, 2015, from http://www.mda.gov.br/portal/saf/programas/alimentacaoe scolar $/ 2478043$

Santa Rosa, P. H., Lucas, A., \& Garavelho, M. E P. E. (2011). Influência do PNAE em uma cooperativa de agricultores familiares de Americana. $19^{\circ}$ SIICUSP, 2011, São Paulo, Resumos Online, USP, São Paulo. Retrieved May 15, 2015, from https://uspdigital.usp.br/siicusp/cdOnlineTrabalhoVisualizarResumo?numero InscricaoTrabalho $=1473 \&$ numeroEdicao $=19$

Soares, S., Souza, L. de, Silva, W., Silveira, F., \& Campos, A. (2016). Perfil da pobreza: Norte e Nordeste rurais. Brasília: Centro Internacional de Políticas Para o Crescimento Inclusivo (IPC-IG)/PNUD.

Souza-Esquerdo, V. F., \& Bergamasco, S. M. P. P. (2013). Programa Nacional de Alimentação Escolar (PNAE) no município de Jarinu-SP: Contradições Reveladas Pela Implementação da Lei 11.947/2009. Retratos de Assentamentos, Araraquara, 16(1).

Wanderley, M. de N. B. (2001). Raízes históricas do campesinato Brasileiro. In J. C. Tedesco (Eds.), Agricultura familiar: Realidades e perspectivas (3rd ed.) Passo Fundo: UPF.

\section{Copyrights}

Copyright for this article is retained by the author (s), with first publication rights granted to the journal.

This is an open-access article distributed under the terms and conditions of the Creative Commons Attribution license (http://creativecommons.org/licenses/by/4.0/). 